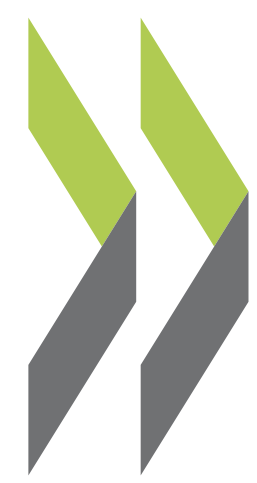

OECD Economics Department Working Papers No. 1235

Reforming the pension system to increase coverage and equity Christine de la Maisonneuve in Colombia 
Organisation de Coopération et de Développement Économiques

Organisation for Economic Co-operation and Development

28-May-2015

ECONOMICS DEPARTMENT

English - Or. English

REFORMING THE PENSION SYSTEM TO INCREASE COVERAGE AND EQUITY IN COLOMBIA

By Christine de la Maisonneuve

ECONOMICS DEPARTMENT WORKING PAPERS No. 1235

OECD Working Papers should not be reported as representing the official views of the OECD or of its member countries. The opinions expressed and arguments employed are those of the author(s).

Authorised for publication by Robert Ford, Deputy Director, Country Studies Branch, Economics Department.

All Economics Department Working Papers are available at www.oecd.org/eco/workingpapers

JT03377332

Complete document available on OLIS in its original format

This document and any map included herein are without prejudice to the status of or sovereignty over any territory, to the delimitation of international frontiers and boundaries and to the name of any territory, city or area. 
OECD Working Papers should not be reported as representing the official views of the OECD or of its member countries. The opinions expressed and arguments employed are those of the author(s).

Working Papers describe preliminary results or research in progress by the author(s) and are published to stimulate discussion on a broad range of issues on which the OECD works.

Comments on Working Papers are welcomed, and may be sent to OECD Economics Department, 2 rue André-Pascal, 75775 Paris Cedex 16, France, or by e-mail to eco.contact@oecd.org

This document and any map included herein are without prejudice to the status of or sovereignty over any territory, to the delimitation of international frontiers and boundaries and to the name of any territory, city or area.

The statistical data for Israel are supplied by and under the responsibility of the relevant Israeli authorities. The use of such data by the OECD is without prejudice to the status of the Golan Heights, East Jerusalem and Israeli settlements in the West Bank under the terms of international law.

\section{(C) OECD (2015)}

You can copy, download or print OECD content for your own use, and you can include excerpts from OECD publications, databases and multimedia products in your own documents, presentations, blogs, websites and teaching materials, provided that suitable acknowledgment of OECD as source and copyright owner is given. All requests for commercial use and translation rights should be submitted to rights@oecd.org 


\section{ABSTRACT/RÉSUMÉ}

\section{Reforming the pension system to increase coverage and equity in Colombia}

Colombia is one of the most unequal countries in Latin America. The high level of informality in the labour market and many characteristics of the pension system leave many elderly in poverty. Only formalsector employees earning more than the relatively high minimum wage are covered. Linking benefits to at least the minimum wage makes the system costly and reduces the provision of annuities by insurance companies as it is difficult to insure against changes in the minimum wage. The Government has recently introduced a matching-contribution scheme (BEPS) for informal workers and vulnerable retiring aged people who have not contributed enough to be entitled to a pension. Moreover, the coverage of the old-age minimum income support has been extended but at the cost of lowering the already modest benefits. More reforms in the pension system are needed to extend coverage while eligibility to the BEPS and the minimum income support should be expanded to guarantee old-age income for more Colombians. In the medium term an in-depth pension reform is required.

This Working Paper relates to the 2014 OECD Economic Survey of Colombia. (www.oecd.org/eco/surveys/economic-survey-colombia.htm)

JEL classification codes: H55, I30, J14, J26, J32

Keywords: pension system, coverage, elderly poverty, inequality, minimum income support, retirement age, minimum wage.

***************************************

\section{Réformer le système de retraite colombien pour en augmenter la couverture et l'équité}

La Colombie est l'un des pays les plus inégalitaires d'Amérique latine. Le caractère très informel du marché du travail, ajouté à de multiples particularités du système de retraite, laisse bon nombre de personnes âgées dans la pauvreté. Ce dernier, en effet, ne couvre que les employés du secteur formel qui gagnent plus que le salaire minimum, relativement élevé. Le montant des prestations doit s'aligner au moins sur le salaire minimum ce qui rend le système coûteux et réduit le volume des rentes payées par les compagnies d'assurance car il est difficile d'assurer une protection contre les variations du salaire minimum. Le gouvernement a récemment mis en place un régime contributif d'épargne-retraite abondé par l'État (BEPS), destiné aux travailleurs du secteur informel et aux personnes vulnérables prenant leur retraite et n'ayant pas suffisamment cotisé pour avoir droit à une pension. La couverture du revenu minimum vieillesse a été étendue, mais au prix d'une réduction de cette prestation, déjà modeste. De nouvelles réformes du régime de retraite sont nécessaires pour en étendre la couverture, mais il convient également d'élargir les critères d'admissibilité au BEPS et aux prestations du revenu minimum pour garantir un revenu à un plus grand nombre de personnes âgées en Colombie. À moyen terme, une réforme approfondie des retraites va s'imposer.

Ce document de travail se rapporte à l'Étude économique 2014 de l'OCDE sur la Colombie. (www.oecd.org/fr/eco/etudes/etude-economique-colombie.htm).

Classification JEL : H55, I30, J14, J26, J32

Mots clés: système de retraite, couverture, pauvreté des personnes âgées, inégalité, revenu minimum, âge de la retraite, salaire minimum. 


\section{TABLE OF CONTENTS}

\section{REFORMING THE PENSION SYSTEM TO INCREASE COVERAGE AND EQUITY IN COLOMBIA5}

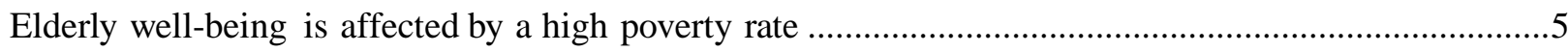

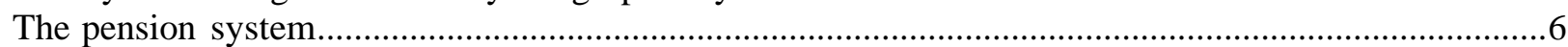

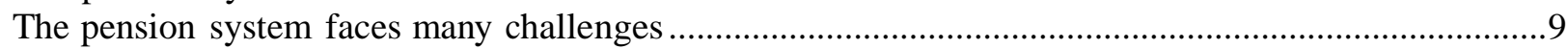

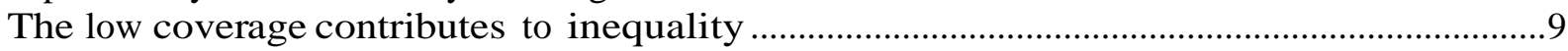

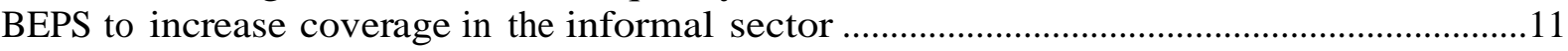

Voluntary saving to the BEPS can also expand contributors ......................................................11

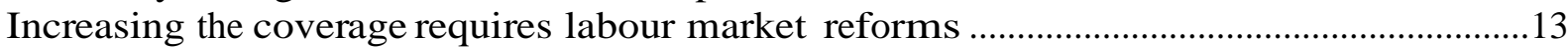

The public defined-benefit plan also raises equity and sustainability issues ........................................14

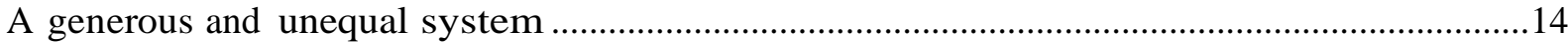

The long-run sustainability of the system is not guaranteed...................................................15

The private defined-contribution plan shies from annuities raising longevity and

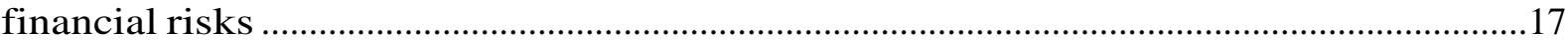

A more ambitious reform of the pension system is needed in the long run .......................................20

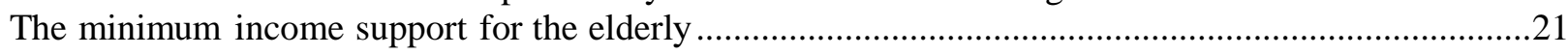

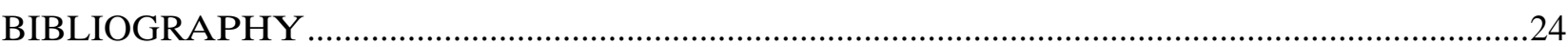

\section{Boxes}

Box 1. The pension system and the old-age income support .........................................................

Box 2. Benefit options in the private defined contribution pension system.......................................19

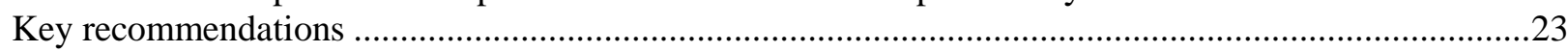




\title{
REFORMING THE PENSION SYSTEM TO INCREASE COVERAGE AND EQUITY IN COLOMBIA
}

\author{
By Christine de la Maisonneuve ${ }^{1}$
}

\section{Elderly well-being is affected by a high poverty rate}

1. Income security is a key element of the elderly well-being (Figure 1). Colombia ranks particularly low, well below the OECD, on this indicator, which measures pension income coverage, poverty rate in old age, relative welfare of older people and GDP per capita. This shows that the Colombian pension and elderly income support system fails to provide an adequate income to most of the elderly. Colombia fares better on other dimensions of elderly well-being. Their health status is better than the OECD average, probably due to the universal health insurance coverage. The perception of the enabling environment, another dimension of elderly well-being, is also better than income security, but well below the OECD average. The enabling environment relates to social connections, physical safety, civic freedom and access to public transport, and is likely to reflect insecurity that prevailed in the country during the past decades as well as the deficient infrastructure.

Figure 1. Well-being of people aged 65 years and more ${ }^{1}$

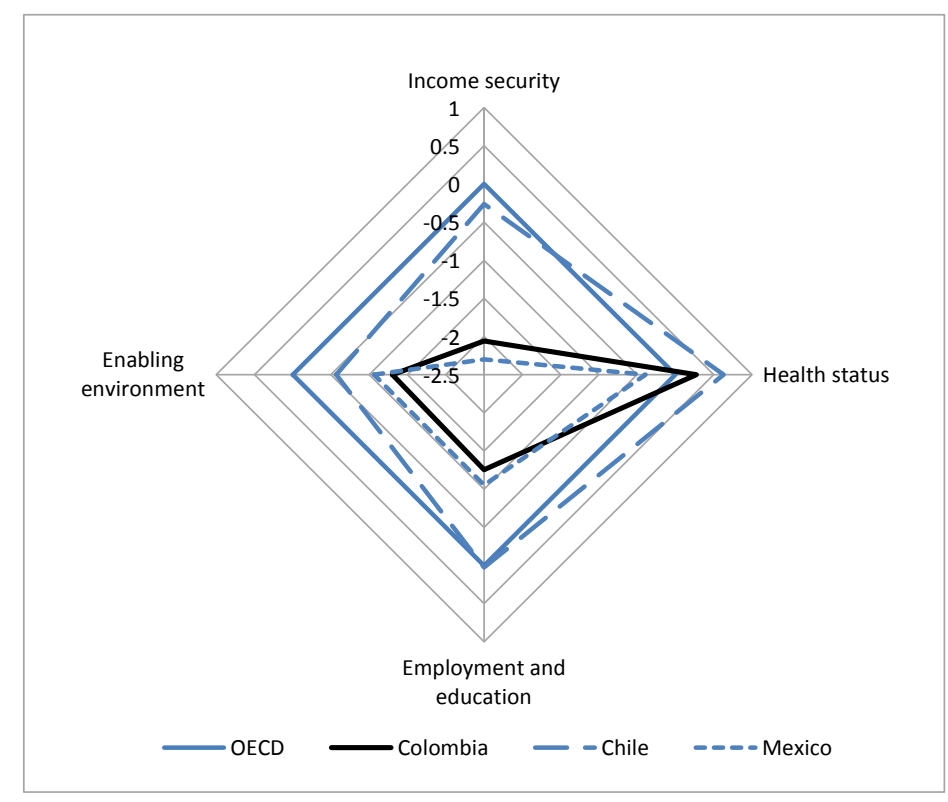

1. Each country's indicator is expressed as the difference with the OECD average and divided by the OECD standard deviation.

Source: HelpAge International (2013).

1. The author is economist in the Colombia desk in the Economics Department of the OECD. This paper is based on material prepared for the 2015 OECD Economic Survey of Colombia published in January 2015 under the authority of the Economic and Development Review Committee (EDRC). This paper is based on Chapter 2 of the 2015 OECD Economic Survey of Colombia published in January 2015 under the authority of the Economic and Development Review Committee (EDRC).The author would like to thank colleagues at the OECD for valuable comments on earlier drafts; Angel Melguizo from the Development Centre, Christian Daude, Robert Ford, Álvaro Pereira and Piritta Sorsa from the Economics Department, Hervé Boulhol, Anna D'addio, Horacio Levy and Andrew Reilly from the Employment, Labour and Social Affairs Directorate, Asees Ahuja and Pablo Antolin from the Financial and Enterprise Affairs Directorate. Special thanks go to Guillaume Bousquet for his valuable data processing contributions and assistance with tables and graphs, as well as Anthony Bolton and Inés Gómez-Palacio for excellent editorial assistance.. 
2. Elderly income insecurity is explained by the fact that most Colombians have no pension and half of the elderly live below the national extreme poverty line. The pension system only covers the few formal sector workers. As a result less than $40 \%$ of elderly (mostly the better off) get a pension, with large subsidies from the general budget. The elderly poverty rate is the highest among 18 Latin American countries (Figure 2). The narrow overall coverage leads to a rise in poverty rate from around $31 \%$ for working-age population to $42 \%$ for people at age 60 and above in contrast to many other Latin American countries (Bosch, Melguizo and Pagés, 2013). The government provides old-age income support for the poor through Colombia Mayor, but the support is well below the poverty line income. It is reflected by the level of spending which is the lowest among Latin America countries (Figure 3). To improve saving for the old age, the government recently introduced a saving scheme, the Beneficios Económicos Periódicos (BEPS), for low-income informal workers but so far the BEPS take-up is low. Financial and material support for the elderly is essentially provided by family members. But population ageing and changing family structures might make this support insufficient. Reforming the pension system and old-age income support is thus becoming urgent to enhance equity, reduce income inequality and improve elderly wellbeing.

Figure 2. Poverty rate of the population older than 65 years (2010)

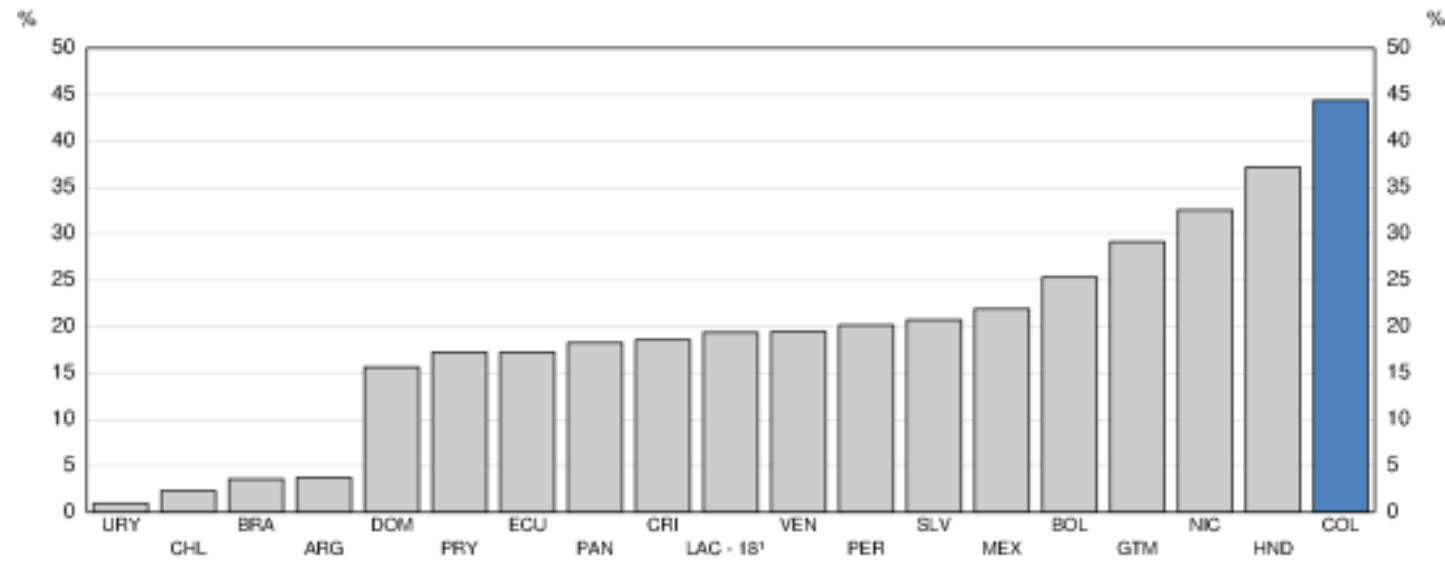

Note: Poverty line USD 2.5/day at PPP.

1. LAC-18 corresponds to the weighted average for the 18 countries.

Source: Cotlear (2011), Banca Interamericano de Desarrollo, HelpAge International Database.

\section{The pension system}

3. In the late 1950s, Colombia created a defined-benefit system for national public employees. In 1967, the Instituto de Seguros Sociales was established to cover people working in the private sector. In 1994, a private defined-contribution plan was implemented. The Colombian General Pension System (GPS) has now two parallel schemes: a public defined-benefit plan and a private defined-contribution plan. Workers must choose between the two schemes, which compete instead of being complementary (Box 1).

4. New entrants to the labour market now mostly choose to contribute to the private definedcontribution plan (Figure 5), as historically (since 1994), average returns in the private definedcontribution plan have been more than $8 \%$ above inflation providing more generous benefits than the public defined-benefit plan. Another difference is that, in the public defined-benefit plan, workers not fulfilling all the requirements for the minimum pension at the end of their careers receive the accumulated contributions adjusted for inflation, while in the private defined-contribution plan the adjustment is for inflation and interest. However, many workers who fulfil the requirement to get a pension, choose to join the public defined-benefit plan when retiring as it is much more generous. Both systems are mandatory. 
Figure 3. Public spending on non-contributory pensions

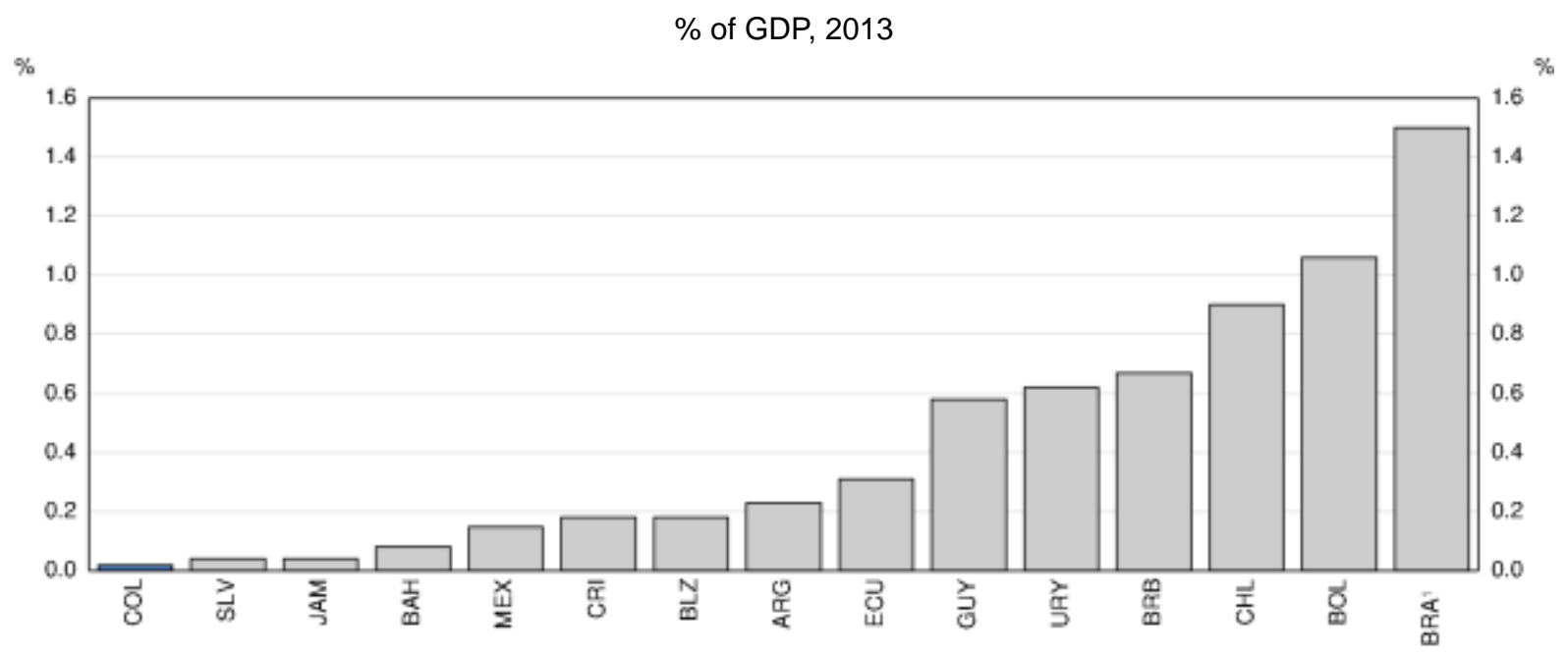

1. For Brazil, it concerns only the rural part of the country.

Source: Cotlear (2011), Banca Interamericano de Desarrollo, HelpAge International Database.

5. Around $36 \%$ of the formally employed are affiliated to the public plan and $64 \%$ to the private plan. Several special regimes complicate the system further (teachers, military, police and oil-company workers). Currently, most of the retirees (96\%) receive a pension from the public defined-benefit plan (including the special regimes) as the private defined-contribution plan has been in place only for 20 years. In both systems, workers contribute $4 \%$ of their salary and employers $12 \%$. Self-employed contribute $16 \%$ on their revenue. 24.5 years ( 25 years as from 2015) of contributions are required for a full pension, which is low compared to OECD and LAC countries (36 years on average in EU countries and 30/35 in Argentina, Brazil, Ecuador and Uruguay and around 38 years in Costa Rica).

6. By Constitution, the minimum pension cannot be lower than the minimum wage. The retirement age is $62 / 57$ for men/women. Only formal workers, earning at least the minimum wage, can contribute to the system. The replacement rate in the public defined-benefit plan ranges between $65 \%$ and $80 \%$ of the average contribution wage for low incomes, between $60 \%$ and $75 \%$ for middle incomes and between $55 \%$ and $70 \%$ for high incomes. It is equal to $100 \%$ for people earning the minimum wage. OECD expected gross average replacement rates are lower $-71 \%$ for a worker earning half the average wage, $54 \%$ for average wage and $48 \%$ for 1.5 times the average wage. Pension benefits are indexed annually to inflation, as in most OECD countries. The minimum pension, however, increases in line with the minimum wage, which has reflected both inflation and productivity gains.

7. Since 2007, Colpensiones is the main administrator of the defined-benefit pension system. Other public defined-benefit administrator entities are the Caja de Sueldos de Retiro de la Policía Nacional (Casur) and the Policía Nacional (both comprise the police regime); the Caja de retiro de las Fuerzas Militares and the Ministerio de Defensa (Cremil) (both comprise the military regime); the Fondo de Prestaciones Sociales del Magisterio (Public Teachers regime) and the Fondo de Previsión Social del Congreso (Congressional regime). The private system is managed by pension funds. 


\section{Box 1. The pension system and the old-age income support}

The pension system comprises two parallel schemes: a public defined-benefit plan and a private definedcontribution plan. Workers must choose between the two schemes, and can switch every five years up to the last ten years before their legal retirement age. In practice, many workers were able to switch after that by going to court. As a consequence, there is competition and overlap between the two schemes, and differing benefits and parallel administrations create inefficiencies (Figure 4). Only formal workers earning at least the minimum wage can contribute to the plans. Contributions are mandatory.

Figure 4. The pension system and old-age income support

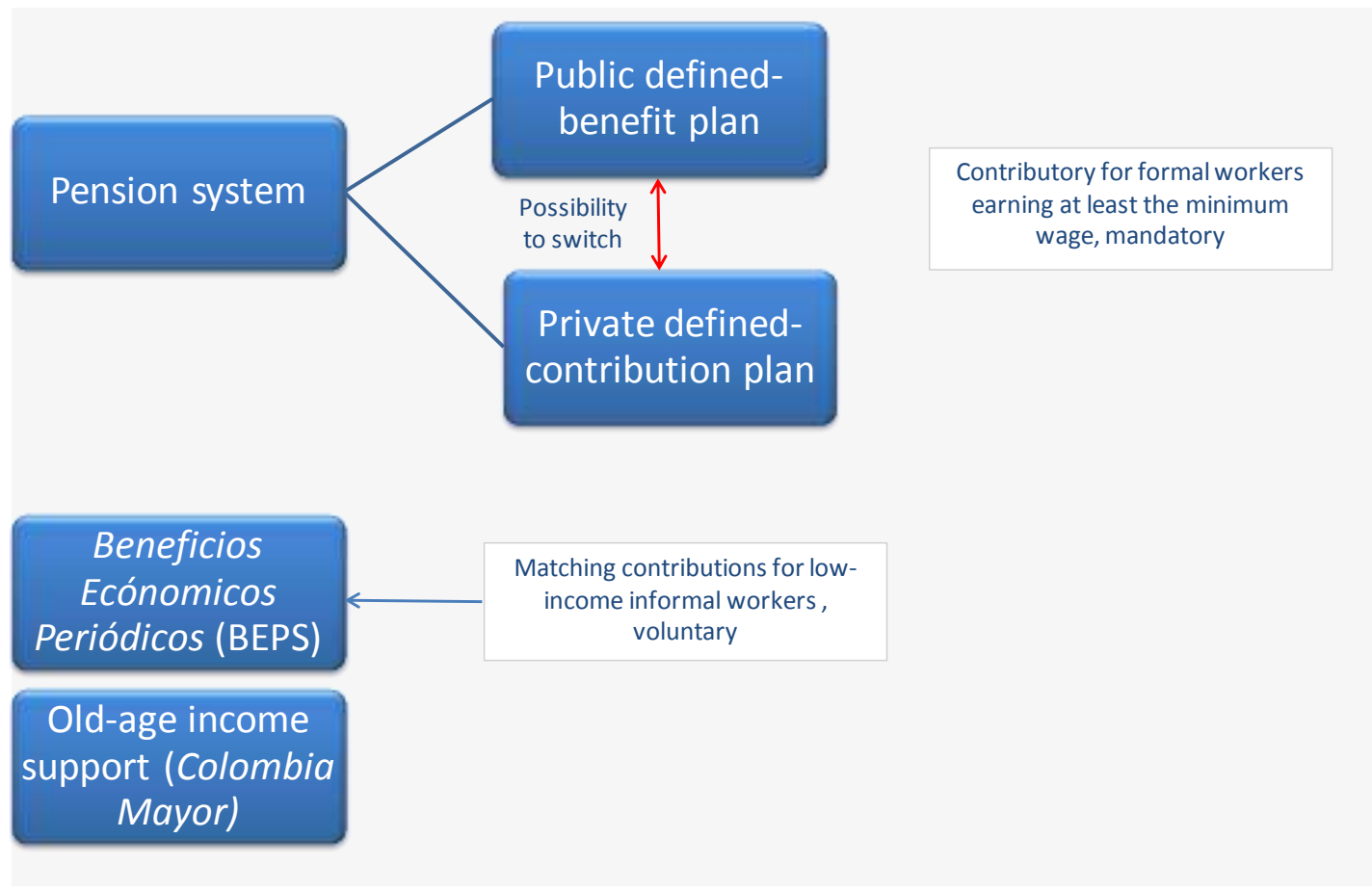

Moreover, for low-income informal workers, the government has introduced a matching-contribution scheme called Beneficios Ecónomicos Periódicos (BEPS). The BEPS target workers with irregular wages due to phases of informal activity. Workers who have not contributed enough to be entitled to a pension can apply for the BEPS.

Finally, for people who spent their entire working life in the informal sector and accordingly have no access to a pension, and who have very low income, the government provides an old-age income support, Colombia Mayor. 
Figure 5. Distribution of contributors by age and scheme, 2013

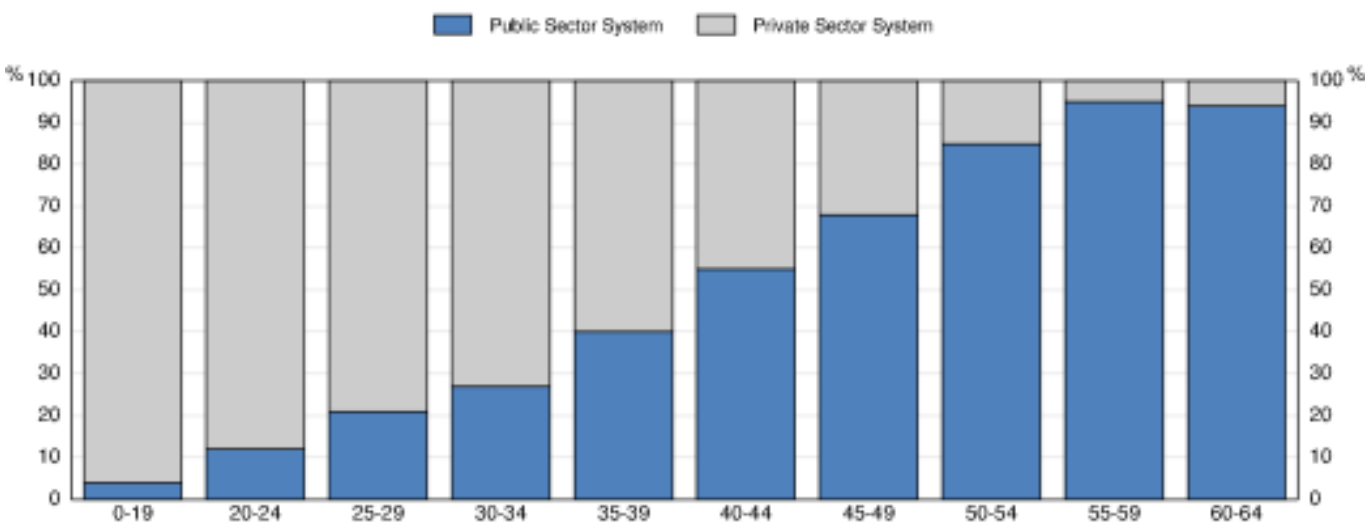

Source: Ministerio de Hacienda y Crédito Público calculation based on information received from the Financial Superintendency and Colpensiones.

\section{The pension system faces many challenges}

\section{The low coverage contributes to inequality}

8. Despite some progress over the past decades, only $37 \%$ of the elderly get a pension, which is low compared to the OECD average (around 90\%) and many Latin American countries-80-90\% in Argentina, Brazil, Chile and Uruguay (Figure 6). Colombia also has lower coverage than countries with similar level of development (Figure 7). There is a strong correlation (around 80\%) between the level of coverage and the level of development measured as the GDP per capita (Holzmann et al., 2009). Part of the elderly $(15 \%)$ are currently covered by special regimes (judiciary, military and police, teachers, among others) that were complementary to the public defined-benefit plan and have now been abolished and transferred entirely to the public defined-benefit plan. Coverage is the lowest among vulnerable groups such as women, workers with low- and medium incomes, working in small businesses or self-employed (Bosch, Melguizo and Pagés, 2013). In rural areas only 10\% are covered, as most of rural workers are informal or earn too little to be able to contribute to the pension system.

Figure 6. Pension coverage in LAC countries

Percentage of people aged 65+ with a pension

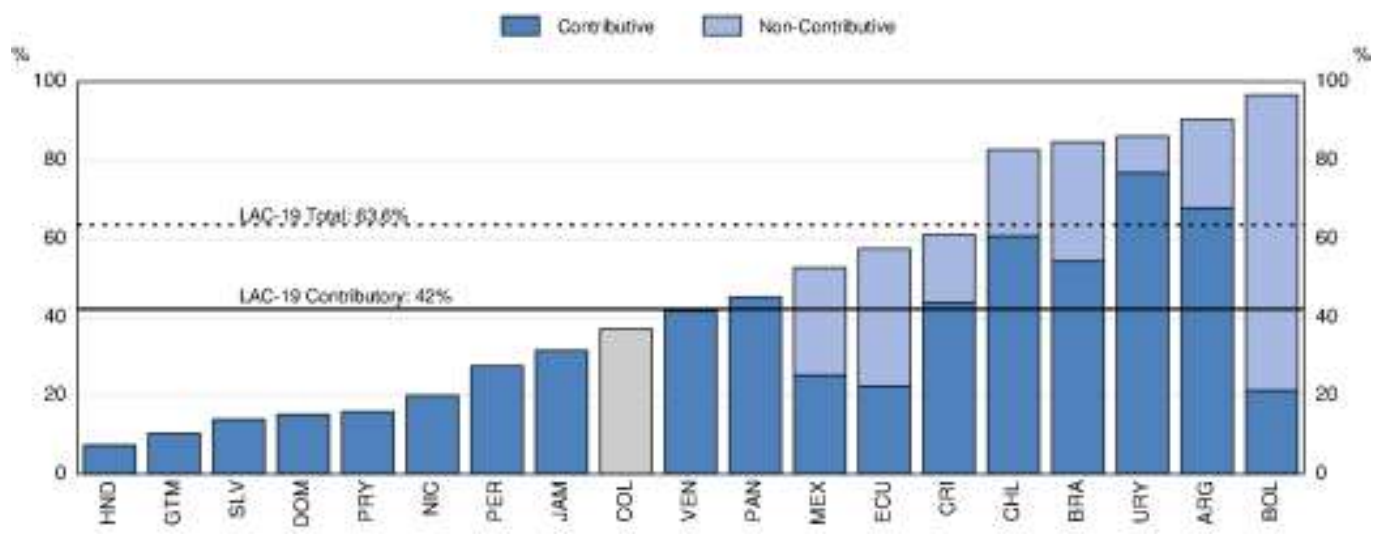

1. The population covered by Colombia Mayor is not included. LAC-19 is the average of the 19 Latin American countries displayed in the chart.

Source: Bosch, Melguizo and Pagés (2013). 
Figure 7. Coverage rates and GDP per capita

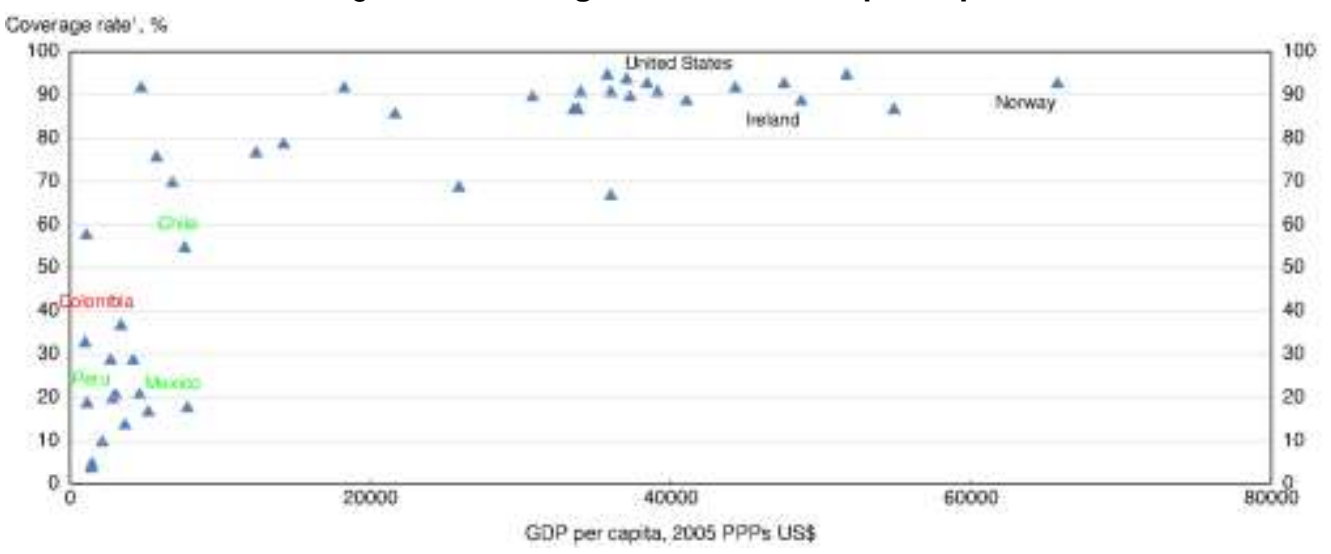

1. Total old-age beneficiaries as a percentage of population aged 65 and over.

Source: Pallares-Miralles, M., C. Romero and E. Whitehouse (2012).

9. The low pension coverage partly reflects the high level of informality. Informal workers, that by definition cannot contribute, account for 50 to $70 \%$ of total employment, depending on the definition (Figure 8). Informality also affects contribution periods. On average people contribute only around 15 years (instead of the 25 required), as most workers face periods of informality. A distinction needs to be made between rural and urban workers. While rural workers often spend their entire life in the informal sector, urban workers face periods of informality followed by periods of formality.

10. The Constitutional requirement that the pension cannot be lower than the minimum wage also affects the level of coverage and benefits. It is costly as the minimum pension represents around $60 \%$ of the average wage while, on average in OECD countries, it represents less than 20\%. Many people reach retirement age without having contributed enough to qualify for benefits at all, as it is difficult to find enough work at the high minimum wage [Only around half of the employed population earns more than the minimum wage (Ministerio de Trabajo, 2012)]. In the private defined-contribution plan, the minimum wage requirement affects the nature of benefits. It discourages insurance companies to participate in the annuity market, as it is difficult to insure against unpredictable changes in the minimum wage. As a result many are forced to take a lump sum at the end of their working lives, instead of annuity that would ensure for longevity risks.

Figure 8. Labour informality and pension coverage in selected LAC countries

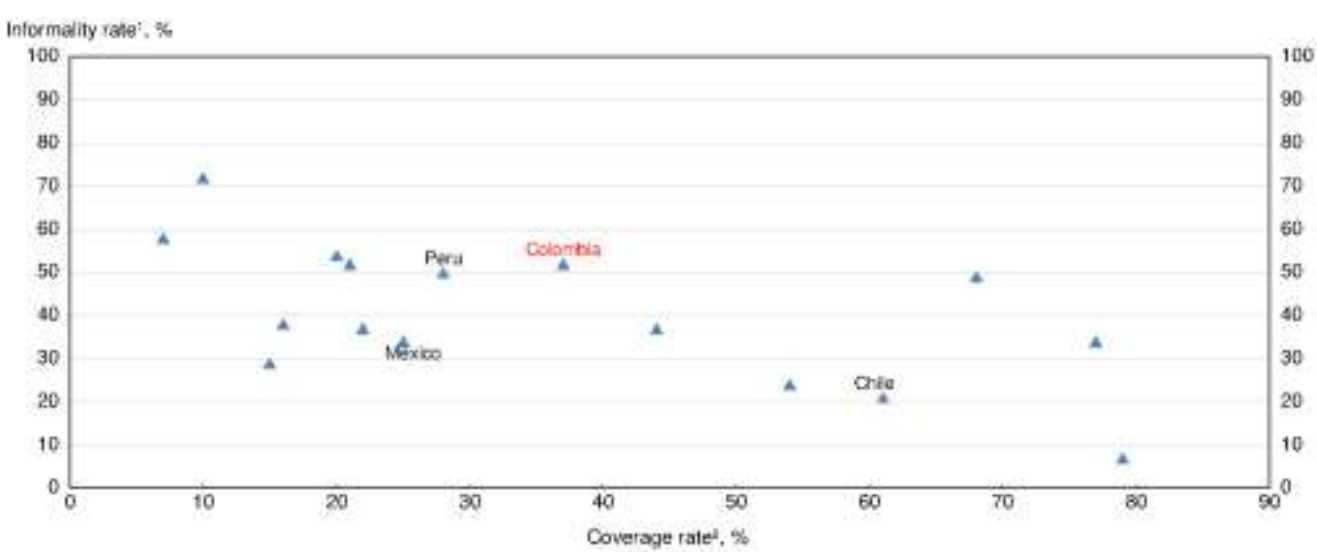

1. People employed in the informal sector as a percentage of total labour force. Informality is defined as workers employed in firms with 5 employees or less.

2. Old-age beneficiaries as a percentage of people aged $65+$.

Source: ILO, Key Indicators of the Labour Market (KILM) database. 
11. To allow more people to be covered by the public defined-benefit plan, the government has implemented the Family pension (Pension Familiar) in 2014. This allows a couple to sum their respective contributed years to fulfilling the requirements. If the joint value is equal or greater than 1.300 weeks (25 years) the couple will obtain one pension. The most important condition to have access to this pension is being in level I, II or III of the Sisbén socio-economic group. The Sisbén system classifies people into 6 socio-economic strata according to income and living conditions and is used to assess eligibility for cash transfers and in-kind services. The introduction of the Family pension will lead to a 5 percentage points increase of the coverage (Montenegro et al., 2013a).

\section{BEPS to increase coverage in the informal sector}

12. To facilitate savings for old-age income (pensions) for the low-income informal workers, the government has introduced a contributory scheme, the BEPS. The BEPS are individual retirement accounts for workers with irregular wages or wages below the minimum wage, or for those who have not contributed enough to the formal sector pension schemes to get a pension. The BEPS targets mostly workers facing phases of informal activity during their working lives. As the scheme has started to be implemented recently, very few retirees have applied for it. The scheme aims at covering 6 to 7 million potentially elderly poor over the next 20 years. People can make voluntary contributions during their active life, for instance, when they face periods of informal work.

13. The BEPS system specifically targets low-income households: only those from the three lower Sisbén level can be covered. The benefit at retirement cannot be more than $85 \%$ of the minimum wage and at least equal to the benefit of Colombia Mayor. However, the coverage of the system is still low, as many low income workers may find it hard to save for some future income in some decades away. At retirement the government subsidises the individual contributions by adding $20 \%$ to the workers' own savings. While this puts fiscal pressure to the future, the lack of subsidy during working lives can undermines participation in the scheme as individuals do not see a direct impact of the incentive. It would thus be useful to provide financial education and information programmes directed specifically towards vulnerable groups to increase awareness and participation. It can be useful, for people facing periods of informality during their working life, to consider combining BEPS with some kind of soft compulsion/auto-enrolment programme to increase participation in the scheme.

\section{Voluntary saving to the BEPS can also expand contributors}

14. Coverage could also be increased by voluntary saving, especially among people who are not currently saving but who would have some capacity. Labour informality is also a middle-class issue. There are more informal than formal workers among the middle-class (Daude, de Laiglesia and Melguizo, 2014) defined as all individuals living in households with adult-equivalent per capita labour income between $50 \%$ and $150 \%$ of the median for the country. In Colombia they represent $50 \%$ of urban workers, of which only $39 \%$ contribute to the pension system. Most of the urban middle-class workers declare their income significantly above the national lines of poverty (three times) which suggests that they have some saving capacity (Figure 9). However, the average amount of the earnings reported is close to the legal minimum wage under which people cannot contribute to the pension system. This is a potentially important pool of people to save for pensions that fall between the BEPS and the formal pension system. 
Figure 9. Workers contributing to the pension system by level of income

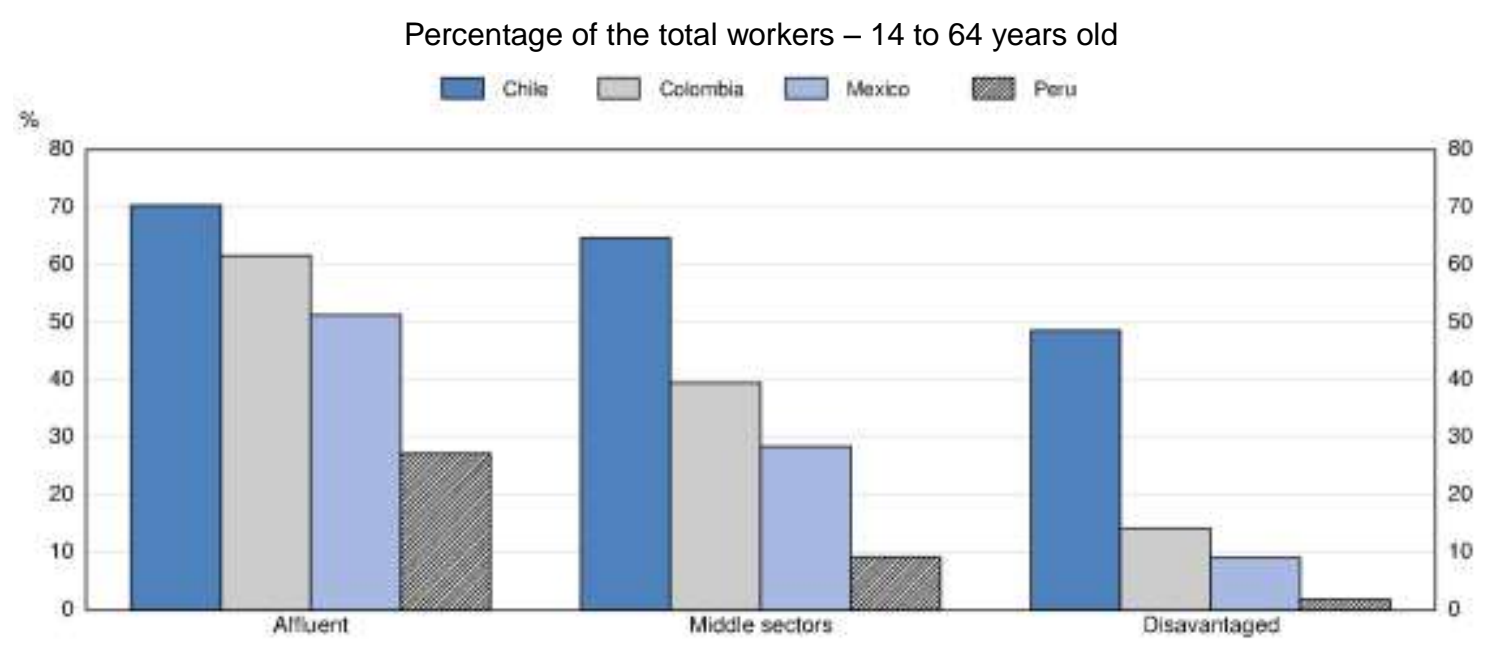

Note: Affiliates who receive a salary in Mexico, contributors in Chile, Colombia and Peru.

Source: Carranza et al. (2012); and Daude de Laiglesia and Melguizo (2014), calculations on household surveys.

15. Many people have moved into the middle-class as wage and employment growth and conditional cash transfers and other social benefits have reduced poverty. Nonetheless, there is a non-negligible risk that many households that have recently moved out of poverty and joined the so-called emerging middle class will prove vulnerable to falling back into poverty if hit by illness, disability or job loss (Daude, de Laiglesia and Melguizo, 2014). These workers may thus face periods of informality during their working career and fail to have all the requirements to have access to a full pension.

16. Many Latin American countries provide incentives to voluntary saving through a so-called "matching-contribution" scheme. These incentives increase the pension savings' financial return by: i) reducing the amount of contributions to access the same level of pension benefits (namely progressive or targeted reductions of social contributions); or ii) increasing the level of pension benefits for the same volume of contributions (by granting a subsidy ex post) (Daude, de Laiglesia and Melguizo, 2014). It is important that incentives from these schemes are lower than those for contributing to the formal scheme.

17. The matching contribution system can provide more tangible incentives for lower- income individuals in the informal sector to participate in pension schemes for the old age than the more traditional approach of mandating participation and providing preferential tax treatment. Informal workers in principle don't benefit from tax incentives. In principle, matching contributions could be provided for public pension programmes, BEPS or by the sponsors of private occupational plans (Hinz et al., 2013). In all of these systems, the matching design feature has the common goal of increasing system participation and saving levels. Directly matching contributions provides an immediate and easily understandable value proposition to prospective entrants to the system. Funding of the accumulated contributions and returns with financial institutions, like the BEPS, should offer credibility, portability, and appropriate returns.

18. Coverage can thus be increased by letting people working in the informal sector (to which belong most of the self-employed and the middle class) and earning less than the minimum wage to contribute to the BEPS. This will reinforce the link between earnings, contributions and pensions. This would imply increasing the eligibility to the BEPS to middle income workers in the informal sector, namely the growing middle-class described above. Moreover, the BEPS should also be extended to more Sisbén strata. Indeed, there are many people who do not earn the minimum wage but are above Sisbén 1 to 3. They should also be allowed to apply for the BEPS. For the time being, the fiscal cost of the BEPS represents only $0.1 \%$ of the GDP per year. 


\section{Increasing the coverage requires labour market reforms}

19. A particular problem for pensions is that many workers enter and exit the formal labour market several times in their career. This results in low contribution densities and therefore insufficient accumulated savings for old-age to fund an adequate pension. Out of 19 million people currently affiliated to the pension system, 5.5 million have not contributed in the last 6 months and an additional 1.4 million have not contributed in the last month. A survey showed that $25 \%$ of workers who are currently in the formal sector will not be within a year. Approximately $6 \%$ will be inactive, $7 \%$ unemployed, $4 \%$ selfemployed and 9\% informal salaried (Goñi, 2013). These figures may underestimate rotations as they do not capture movements within a year. Moreover, they may be biased as they use cross-sectional data and consequently fail to follow workers over time. Nonetheless, they show the extent of the problem. Greater coverage can thus be achieved by either labour market reforms that create more formal jobs or amending the system to enable more contributions while in informal employment. One key constraint is the requirement of a minimum wage for contributions, and that around $50 \%$ of workers earn less than that.

20. Thus, reforming the minimum wage becomes key to both pension and labour market reforms. The problem is more acute in the low income regions of Colombia. The minimum wage as such is not the problem but the fact that it has been increased in recent years by inflation and formal sector productivity. This explains the high level compared to average wage, and is pricing many workers out of the formal sector. The increase of the minimum wage should thus be limited to inflation only and possibly differentiated by age.

21. High non-wage labour costs is another factor keeping workers in the informal sector. For instance, a 10\% increase in payroll taxes in the 1990s lowered formal employment by between 4\% and 5\% (Kugler and Kugler, 2008). Other countries' experience shows that lowering social security and other nonwage labour costs contributions can help broadening the contribution base e.g. by including the selfemployed (Chile and MEI programme in Brazil), the youth, the SMEs (Brazil SIMPLES programme) (Bosch, Melguizo and Pagés, 2013). More should be done to reduce non-wage labour costs further. One option is to remove the $4 \%$ contribution on wages that finance the Cajas de Compensación system, which are non-profit private entities that provide family allowances, unemployment insurance and commercial and recreational activities. Recreational and commercial activities should become voluntary. This lowering of the contribution would boost job creation and increase the number of contributors to the system.

22. Raising the level of education should also help increase formal jobs and thus coverage. The latest PISA survey shows some improvements but overall the Colombia score remains low compared with OECD countries. Pre-primary and tertiary enrolments should be further increased in particular by targeting students with low socio-economic backgrounds. The quality of education should also be increased (OECD, 2013a). The education system should ensure that tertiary qualifications match the skill requirement of the labour market which is often not the case.

23. Another option in the near term is to relax the constraint that pensions must be at least equal to the minimum wage, but this would require a difficult constitutional reform. Another possibility is to give people, who reach retirement age with less than the required number of years, a partial pension. This pension would be equal to the minimum pension adjusted for the difference between the effective contribution period of the retiree and the mandatory 25 years. Then, if the retirees find their income too low, during the first years of retirement they could have the possibility to buy weeks of contributions. In practice, this means that they will keep paying contributions to the pension system while in retirement. Once they have reached the mandatory 25 contribution years, they will receive the full minimum pension (which will then be equal to the minimum wage). 


\section{The public defined-benefit plan also raises equity and sustainability issues}

24. Since 2012, Colpensiones has been the main administrator of the public defined-benefit plan and managed about $48 \%$ of total public pensions. Pension benefits paid by Colpensiones are financed on a payas-you-go basis, in which the government fills the gap when contributions fall short of outlays, as has been the case since 2004. Overall, in 2013, the number of pensions amounted to around 2.3 million and the public expenditure to above 35 trillion of COP, or around 5\% of GDP.

\section{A generous and unequal system}

25. The public defined-benefit plan raises serious equity issues by exacerbating inequality as it mainly benefits high-income formal workers. More than $80 \%$ of pensions go to the highest income quintile while the two poorest quintiles receive less than 2\% (Santa María et al., 2010). For instance, the reference salary is calculated using the last 10 years of earnings, which benefits those with steep earnings profiles (Montenegro et al., 2013b). They are often the best educated and high-income individuals (OECD, 2013a). By contrast, in 21 OECD countries, the pension is based on lifetime earnings and in some others on 25-35 years of earnings (OECD, 2013b).

26. Colombia should consider increasing the number of years on which the reference salary is based. It will help people facing period of informality at the end of their career, namely the low educated people, to enjoy a higher pension. It is estimated that the subsidies to the higher income can be largely reduced by taking into account 40 years as reference salary (Montenegro et al., 2013b). Nonetheless, this adjustment will not be sufficient to eliminate all the subsidies to high income workers, in particular for women in the top income decile. An increase in the retirement age for both men and women until 65 will almost eliminate all the subsidies to high income earners (Montenegro et al., 2013b). The equity of the system will thus be enhanced as public subsidies will benefit mostly low-income people (especially women belonging to the 1 st to the 5 th income decile).

27. The generosity of the public defined-benefit plan for the few who have access to a pension also makes it expensive to extend eligibility. The replacement rate is high in comparison with OECD countries (Figure 10), and is particularly high at $100 \%$ for people earning the minimum wage. Lowering the gross replacement rate from above $70 \%$ (for the median earner, OECD, 2014) towards around 37\% (or slightly above that number as it is based on a rate of return of $3.5 \%$ which may be on the low side) of the private defined-contribution plan would eliminate the arbitrage between plans and reduce the subsidies to the rich OECD/IDB/WB (2014).

Figure 10. Gross pension replacement rates in $2013^{1}$

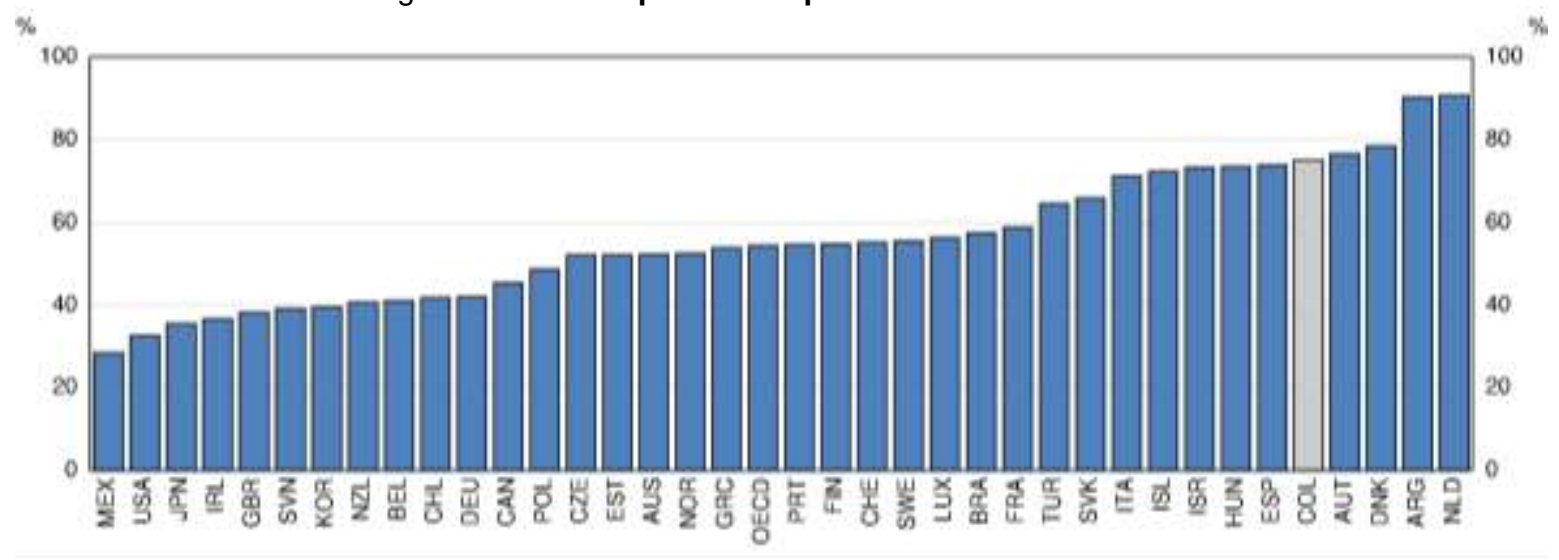

1. Expected gross replacement rate of a man earning one average wage. For Colombia, it represents the upper bound of the middle incomes' replacement rate in the public pension scheme.

Source: National Authorities and OECD (2013b). 
28. Generous tax treatment also leads to inequality. The contributions are deductible from the income tax base, the returns on pension investment are not taxable, and the benefits are largely tax exempt. These very generous features also add to the low revenue collection problems faced by the Colombian tax system. They need to be addressed in a broader tax reform (Daude, Perret and Brys, 2015). The personal tax system plays an important role in old-age support in OECD countries. The average tax rate on pension income is typically less than the tax rate on earned income. In addition, most income tax systems give preferential treatment either to pension incomes or to pensioners, by giving additional allowances or credits to older people (OECD, 2013b). Colombia should consider taxing pension benefits in a progressive way as in most OECD countries ((Daude, Perret and Brys, 2015).

\section{The long-run sustainability of the system is not guaranteed}

29. The long-run sustainability of the system may also be at risk. The dependency ratio will rise from $10 \%$ today to around $35 \%$ in 2060 , approximately the same trend as the Latin America average (Figure 11). The situation is worse when looking at the economic dependency ratio which compares the number of people aged 65 and over with the number of total employed people (the ones potentially contributing to the pension system, i.e. including informal employed). As a consequence of population ageing, the non-contributory part of the regime will also increase significantly and put pressure on public finances. According to recent projections, the highest level of pension expenses in the national budget would be between the years 2014 and 2018. Current pension liabilities are estimated at about 129\% of GDP in net present value terms for the next 50 years (Santa María and Piraquive, 2013). This is relatively modest compared to OECD and emerging markets, but large in view of the low coverage.

Figure 11. Dependency ratio

Population aged $65+$ as percentage of the population aged $15-64$

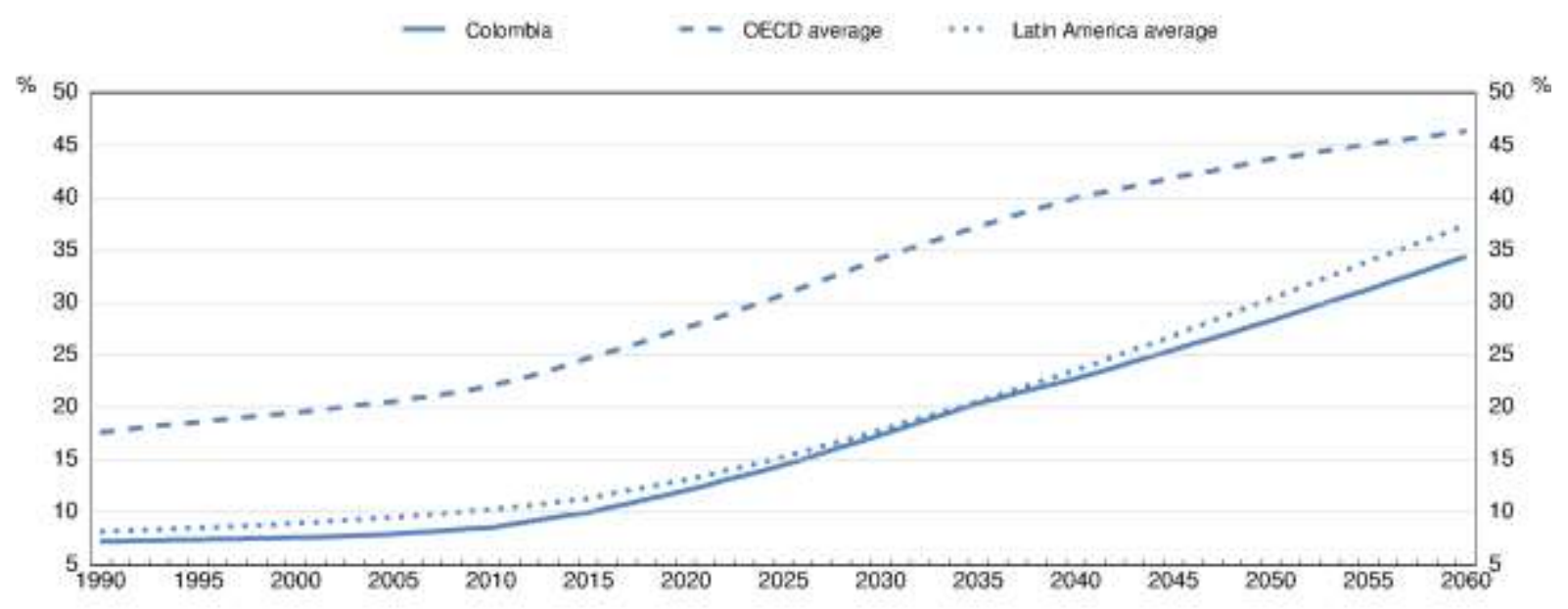

Source: UN population projections database.

30. Changing the current generous parameters can bring some important savings. Simulations show that lowering the replacement rate of the public plan towards that of the private one, increasing the number of years of contributions from 10 to 20 or raising the retirement age by 5 years for both men and women would decrease the net present value (NPV) of pension liabilities from 129\% to 120\%, 126\% and 122\%, respectively. Overall, if the three parameters are modified, the reduction will be quite significant, amounting to almost twenty percentage points of GDP at below $110 \%$ of GDP. These adjustments will help financing the extension of the BEPS and Colombia Mayor programmes whose liabilities are estimated at about $8.5 \%$ of GDP in net present value terms over the next 40 years (Santa María and Piraquive, 2013). 


\section{ECO/WKP(2015)53}

31. IMF estimates also suggest that modifying the system parameters can lead to a substantial reduction of the NPV of pension liabilities, calculated at 106\% of GDP over the period 2012-50. For instance, a simulation of several combined adjustments - reducing the replacement rate of the public system; increasing the number of years of the reference wage (from 10 to 20); equalising the retirement age of men and women and then linking it to the evolution of life expectancy; eliminating the 13th month payment; reducing the pensions of the armed force by 20\%; and imposing an extra $10 \%$ solidarity surcharge on pensions above 5 minimum wages - leads to a reduction of the NPV of pension liabilities by 23 percentage points.

32. Raising the retirement age further should also be considered in the medium term. The retirement age, at 62 for men and 57 for women, is low compared to the average OECD countries ( 65 and 63.5, respectively). Life expectancy at birth has increased by more than 3 years per decade since 1960 , slightly above the OECD average. It is now at 78 years for women and 70 years for men in Colombia, while it is at 83 years for women and 77 years for men on average in OECD countries. The IMF estimates that life expectancy at retirement age will rise in Colombia by 2.6 years for men and 3.3 years for women from now to 2050 (Table 1). The share of people aged 80 and over in total population will rise from $1 \%$ currently to more than $6 \%$ in 2060.

Table 1. Statutory retirement age and life expectancy at retirement

$$
\text { 2010-50 }
$$

\begin{tabular}{|c|c|c|c|c|c|c|c|c|}
\hline & \multicolumn{2}{|c|}{ Statutory retirement age } & \multicolumn{2}{|c|}{$\begin{array}{l}\text { Life expectancy at } \\
\text { retirement age } 2010\end{array}$} & \multicolumn{2}{|c|}{$\begin{array}{l}\text { Life expectancy at } \\
\text { retirement age } 2050\end{array}$} & \multicolumn{2}{|c|}{$\begin{array}{c}\text { Increase in life } \\
\text { expectancy at } \\
\text { retirement } \\
\text { age } \\
2010-2050 \\
\end{array}$} \\
\hline & Men & Women & Men & Women & Men & Women & Men & Women \\
\hline Argentina & 65 & 60 & 15 & 19 & 18 & 22 & 3.0 & 3.3 \\
\hline Bolivia & 58 & 58 & 19 & 21 & 24 & 26 & 4.7 & 5.3 \\
\hline Brazil & 65 & 60 & 17 & 19 & 19 & 22 & 2.9 & 3.0 \\
\hline Chile & 65 & 60 & 17 & 20 & 19 & 23 & 2.5 & 2.8 \\
\hline Colombia & 62 & 57 & 19 & 25 & 21 & 28 & 2.6 & 3.3 \\
\hline Costa Rica & 65 & 65 & 18 & 20 & 20 & 23 & 2.5 & 3.0 \\
\hline Dominican Republic & 60 & 60 & 21 & 23 & 23 & 26 & 2.4 & 2.6 \\
\hline Ecuador & 60 & 60 & 21 & 23 & 24 & 26 & 2.7 & 2.9 \\
\hline El Salvador & 60 & 55 & 20 & 23 & 23 & 26 & 3.0 & 3.3 \\
\hline Guatemala & 60 & 60 & 19 & 22 & 22 & 25 & 2.9 & 3.4 \\
\hline Honduras & 65 & 60 & 16 & 18 & 18 & 21 & 2.3 & 2.9 \\
\hline Mexico & 65 & 65 & 17 & 19 & 19 & 22 & 2.6 & 3.1 \\
\hline Nicaragua & 60 & 60 & 20 & 23 & 23 & 26 & 3.2 & 3.4 \\
\hline Panama & 62 & 57 & 19 & 26 & 22 & 29 & 2.5 & 3.3 \\
\hline Paraguay & 60 & 60 & 19 & 21 & 22 & 24 & 2.4 & 2.7 \\
\hline Peru & 65 & 65 & 62 & 18 & 18 & 21 & 2.5 & 3.1 \\
\hline Uruguay & 60 & 60 & 19 & 23 & 22 & 27 & 3.5 & 3.3 \\
\hline Venezuela & 60 & 55 & 17 & 19 & 21 & 28 & 3.7 & 8.7 \\
\hline Average & 62 & 60 & 18 & 21 & 21 & 25 & 2.9 & 3.5 \\
\hline
\end{tabular}

Source: IMF staff calculations. 
33. The retirement age has just been increased by two years this year so it may be politically difficult to increase it further in the near future. Nonetheless, in a first step, equalising the retirement age between men and women would raise female pension coverage through longer contribution periods and higher chances to fulfil the requirement while addressing part of the sustainability issue. In the longer term, as it is done in most OECD countries, Colombia should gradually move towards a scheme that links, to some extent, the retirement age to life expectancy. This would raise long-term sustainability. For that purpose, the experience of many OECD countries could help Colombia to implement this reform.

\section{The private defined-contribution plan shies from annuities raising longevity and financial risks}

34. The private defined-contribution plan provides three kinds of benefits to its affiliates: i) Disability pension plan; ii) Survivor's pension plan; and iii) Retirement pension plan. The market is concentrated in only 4 funds: Protección, Porvenir, Colfondos and Old Mutual. The market share of the two largest funds is over $80 \%$ in terms of both members and assets. They are owned by the main economic conglomerates of the country. This level of concentration is quite common in Latin American countries (for instance in Chile, Costa Rica, and Peru), and can lead to high costs and fees. Compared with other Latin American countries, operating costs are higher in Colombia. However, a smaller market can facilitate a closer supervision of the actors, provided that the independence of the supervision is guaranteed.

35. Since their creation, the private pension funds have developed an important role in the financial system and have been vital to boosting the development of local capital markets. Since the mid-90s, they have been active participants in the public debt market and now, by the level of assets they have on their balance sheet, they are major investors in government treasury securities. In macroeconomic terms, the Pension Fund Administrators (PFA) play a key role in generating and allocating savings. Through the PFA, private savings are channelled, delivered to professional managers and used to finance projects of public and private investment. In the near future, the pension funds will have an important role in the development of large infrastructure programme in Colombia. They will be part of the investors who will be financing a set of projects such as roads and airports, in partnership with the government agency of infrastructure, through the mechanism of public-private partnerships.

36. Participants can choose between various portfolios for their pension savings. The multifondos consist of three different portfolios with different investment regimes, depending on the affiliates' age and risk preferences - the conservative fund, the moderate fund and the high risk fund:

- Conservative fund: For members with a low risk profile. Its priority is to preserve the capital of the individual account and its target are members who are close to receive their pension benefits and prefer to obtain less returns than to be worried about possible investment losses.

- Moderate fund: For members with a moderate risk profile. These members should be willing to accept possible investment losses due to the risk exposure of this fund, looking for greater returns in the long term, in comparison with the conservative fund.

- High-risk fund: For members with a high risk profile. These members are far from receiving their pension benefits and are willing to accept higher volatilities that can result in important investment losses as a consequence of the risk exposure of this fund, looking for greater returns in the long term, in comparison with the moderate fund. 
37. The member of the pension fund must choose between one of these funds based on the information given by the pension fund manager. In all cases the investments must be made and must be directed by the pension fund manager, according to the risk regime chosen by the member. The aim of this mechanism is to have a better return rate at the end of the capitalisation period.

38. Retirement benefits are based on the amount accumulated in the member's individual account. Accordingly, they depend on both the salary of the worker and the return of the saving. The gross replacement rate ranges roughly between $34 \%$ and $107 \%$ - the latter corresponding to the minimum salary earners. These estimates do not reflect actual salary development of the contributors or additional insurance companies' operating fees. In reality salary development can take a parabolic shape for low- and medium-income workers, while it keeps growing for high-income workers. This might translate into an overestimation of the high-income workers' replacement rate and an underestimation of the medium income worker's one.

39. Many pensioners in the private scheme have included in their accounts a bond ("Título pensional"). This is a transitory measure applied after the 1993 reform. The Titulos pensionales are guarantees for the pensions that firms were paying directly to their employees before the 1993 reform. These rights can be included in the individual accounts of workers. It accounts for years of contribution raising thereby the replacement rate. In many cases it gives them a replacement rate higher than what current contributors can expect. In some cases the replacement rates for people who could include this bond are even higher than those in the public scheme.

40. Members can decide between seven benefit options (Box 2). The member can retire at any time from the PFA if the balance in a member's account is sufficient to finance a monthly benefit of more than 110 percent of the minimum monthly national salary. Members aged 62 (men) and 57 (women) who have contributed for at least 1.150 weeks, but whose individual account balance is not sufficient to finance a monthly benefit of at least the minimum monthly national salary, are entitled to obtain the minimum pension from the Minimum Pension Guarantee Fund. This minimum benefit is financed with 1.5 percentage points out of the total $16 \%$ contribution rate. Members aged 62 (men) and 57 (women) who have contributed for less than 1.150 weeks, and whose individual account balance is insufficient to finance a monthly benefit of at least the minimum monthly national salary, are entitled to a refund of their individual account balance.

41. Given that the private defined-contribution plan is a capitalisation one, the age of retirement and the benefits depend on the sum that is accumulated on the affiliate's saving account. It gives rise to two types of risks: longevity and financial. Longevity risk describes the case where the worker/insured lives longer than his or her life expectancy and thus faces the risk of exhausting accumulated funds to pay the pension. Financial risk stems from the value of pension savings being tied to the return on investments made in financial markets, whose volatility can, in poor market conditions, generate negative return rates (Bosch, Melguizo and Pagés, 2013).

42. In defined-benefit systems, the government, or the public or private entity promoting the plan, assumes both the longevity and the financial risks during the active and retirement life of the contributor. In defined-contribution systems, the contributor assumes the longevity and the financial risks during his or her active life. Upon reaching retirement age, the contributor can opt for two different products: an annuity or a scheduled withdrawal, or, sometimes, a full withdrawal of the funds. If the insured opts for an annuity, he or she must hand over the accumulated capital to an insurance company that will then assume both the longevity and financial risks. If the insured chooses a scheduled withdrawal, he or she maintains control of the accumulated amount and the fund administrator will pay the insured a monthly sum, which will be recalculated annually based on financial performance and the updated estimated life expectancy. Therefore, the contributor also assumes the longevity and financial risks during his or her passive life. 


\section{Box 2. Benefit options in the private defined contribution pension system}

- Life pension annuity, in which case they transfer the accumulated capital in their individual account to a life insurance company of their choice to purchase a monthly annuity of at least the minimum benefit. Once made, this choice is irrevocable.

- Programmed withdrawal, in which case the Pension Fund Administrator holds the accumulated capital in the individual account and pays the retirement benefit. Whilst a member is receiving programmed withdrawal benefits, the remaining accumulated capital in the individual account must be enough to finance a life annuity at least equal to the minimum monthly national salary.

- Programmed withdrawal with deferred life annuity, in which case part of the accumulated capital in their individual account is transferred to a life insurance company of their choice to purchase a life annuity payable from an agreed date. The remaining capital is used to provide a temporary income until this date. The deferred annuity must not be lower than the minimum benefit.

- Defined Temporary income with deferred life annuity, in which case the beneficiary arranges the payment with a life insurance company of a specific income and a deferred life annuity, which will begin at the moment the defined temporary income period ends.

- Variable temporary income with deferred life annuity, in which case the member can elect to receive a higher benefit payment during the variable temporary income period and lower during the deferred life annuity, or vice versa, depending on the member's needs.

- Programmed withdrawal without negotiating the recognition bond, in which case the member begins to receive the benefit before redemption of the recognition bond issued, under the programmed withdrawal programme without negotiating such bond.

- Variable temporary income with immediate life annuity, in which case an insurance company pays the member an immediate life annuity at the moment of retirement, holding in the individual account the necessary resources for the PFA to pay simultaneously a variable temporary income during the period agreed with the PFA.

43. Currently, only around $15 \%$ of payments are done through life-time annuities, compared to between 20 and $75 \%$ in OECD countries. This rather low level is influenced by the requirement that the minimum pension has to equal the minimum wage, which discourages insurance companies to participate in the annuity market, as it is difficult to insure against changes in the minimum wage. The government is planning to cover this risk. If the increase in the minimum wage is above inflation, the government will guarantee the payment. By contrast, if the increase is lower, insurance companies will be indebted to the government. A minimum level of annuitisation for the benefit pay-out phase should be encouraged to improve protection against longevity risk. A combination of programmed withdrawals with a deferred life annuity that offers protection against inflation could be seen as an appropriate default (OECD, 2012). The demand for annuities could be also promoted by financial education initiatives stressing that they are insurance products designed to protect people from outliving their resources (OECD, 2012). 


\section{A more ambitious reform of the pension system is needed in the long run}

44. In the short term, some adjustments should be implemented to make the pension system sustainable and increase its coverage and equity. The eligibility to the BEPS should be extended to all workers earning less than the minimum wage, which includes most of the self-employed and the middle class. Some characteristics of the public defined-benefit plan may also be adjusted. The replacement rate should be decreased towards the private defined-contribution one and the reference salary based on more years of earnings. In the medium-term, the retirement age should be increased and linked to life expectancy. Nonetheless, all these adjustments will probably not be sufficient to ensure the long-run sustainability and equity of the system.

45. The complexity of the system and the many adjustments required to make it more equitable and sustainable suggest that a comprehensive pension reform is needed in the medium to long term. Such a reform should aim at building a comprehensive multi-pillars system. It should extend the old-age income support (Colombia Mayor), which would become pillar 0. The competition between the public definedbenefit and the private defined-contribution plans should be removed as it is costly and inefficient. There are several options regarding the contributory part of the system. The current private defined-contribution plan (pillar 2) could be complemented by a basic public defined-benefit plan (pillar 1). In this case, the generosity of the public plan should be reduced significantly. Alternatively, the public defined-benefit plan could be gradually phased out. Relaxing the constraint of the minimum pension to be at least equal to the minimum wage would also be key to increase coverage. Through the BEPS, the Government would subsidise the contributions of low-income workers inside pillars 1 or 2. Voluntary contributions to the private defined-contribution plan would form the 3rd pillar.

46. Phasing out the public defined-benefit plan (and moving to a contributory system) would lower liabilities by more than 18 percentage points of GDP in the next 50 years (Santa María and Piraquive, 2013). This scenario stipulates that from now on, no new worker would be allowed to contribute to the public system. The first 10 years will see no impact as working people will keep on contributing for retirees. In the following 15 years, the transition will cost between 0.3 and 0.6 percentage points of GDP compared to the baseline. After 2035, the cost will be lower than in the baseline. Overall, with such a reform, the net present value of pension liabilities will reach around $110 \%$ of GDP from almost $130 \%$ in the baseline.

47. In the case of the phasing out the public defined-benefit plan, the transition to the new system should be as smooth as possible. Only new workers would be obliged to contribute to the definedcontribution system. Workers already in the labour market should make a definite choice between the defined-benefit and the defined-contribution plan. Attention should be paid to transitional costs to the budget, which can be financed, for example, by a "pension bond", which as a one-off payment could fall outside the fiscal rule. Over the long term it will allow the pension system in Colombia to be sustainable and more equitable.

48. Colombia could benefit from OECD experiences in reforming pension systems. Definedcontribution plans are available in around one third of OECD countries while defined-benefit or point systems are available in the rest. None of the OECD countries has a parallel system like the one in Colombia. Most OECD countries have implemented pension reforms in recent years to reduce old-age poverty and to address ageing of their population and the subsequent unsustainability of the systems. First, reforms of public pension systems have introduced higher pension ages (at least 67 years in most OECD countries by around 2050), automatic adjustment mechanisms and modified indexation rules. These are to improve financial sustainability of pension provision. Second, governments have been looking at private pension arrangements. For instance, the Czech Republic, Israel and the United Kingdom have introduced defined-contribution pension schemes (OECD, 2013b). 


\section{The minimum income support for the elderly}

49. To deal with old-age poverty, Colombia has recently introduced Colombia Mayor- previously called Programa de Protección Social al Adulto Mayor (PPSAM) - and the PSAP (Programa de Subsidio al Aporte en Pensión) financed from the social security system. Colombia Mayor is financed by levies on higher salaries. Employees with a monthly contributory base salary higher than four times the minimum wage must make additional contributions to the Solidarity Pension Fund, which finance Colombia Mayor (on a scale from 1 per cent on four times the minimum wage to 2 per cent on 20 or more times the minimum wage).

50. The coverage of Colombia Mayor has been extended from almost 900000 recipients in 2010 to more than 1.2 million in 2014. It covers $36 \%$ of the population aged 65 and over. The PSAP programme has around 200000 beneficiaries, of which $82 \%$ are independent workers in cities, $16 \%$ rural workers, $1 \%$ communitarian mothers, $1 \%$ town councillors and $0.3 \%$ disabled people. The coverage of both schemes together is about the average of OECD countries for old-age income support (Figure 12, Panel A). To be eligible, a person should be at least 65 years old and belong to the Sisbén 1 and 2 groups (social groups based on income levels).

51. However, the average benefit in relative terms is below all OECD countries except Korea (Figure 12, Panel B). The recent significant expansion of the coverage has led to a decrease of the benefit by $50 \%$. At currently around $10 \%$ of the minimum wage or $7 \%$ of the average wage, it is below the national extreme poverty line.

52. Colombia should increase old-age income support, while ensuring that work incentives are preserved. The level of income support and pensions may impact the decision of people to participate in the labour market as indicated by the experience of some Latin American countries. Having access to a non-contributory pension can seriously reduce the labour supply of eligible beneficiaries (Bosch, Melguizo and Pagés, 2013). For instance, a number of programmes to reduce poverty and inequality among elderly especially in rural areas - Previdencia Rural in Brazil, the moratorium programme in Argentina, and the rural programme 70+ in Mexico - have resulted in a considerable reduction in the labour supply of individuals eligible for a non-contributory pension, ranging from 5 to 11 percentage points (Carvalho Filho, 2008; Bosch and Guajardo, 2012; Rodrigues de Oliveira and Kassouf, 2012; Juárez and Pfutze, 2012). However, the labour supply effect is smaller when the programme is targeted to the poor (Olivera and Zuluaga, 2014).

53. Colombia Mayor avoids the incentive problem by targeting people with very low or no income. Those covered are mainly workers who spend all their life in the informal sector, mostly in rural areas and with low education levels. The welcome extension of Colombia Mayor to 2.4 million beneficiaries as envisaged by the government, should not create bad incentives to stay in the informal sector. However, the average benefit should be raised to allow more people to get out of poverty. It should be at least double to get closer to the average relative support levels in OECD countries. The NPV of liabilities of such a change will be less than $10 \%$ of GDP over the next 40 years compared to $4.4 \%$ with the current settings (Santa María and Piraquive, 2013). There should be budgetary room to increase support, as elderly income support is a small share of the budget and the lowest among Latin America countries. 
Figure 12. Coverage and value of minimum pensions
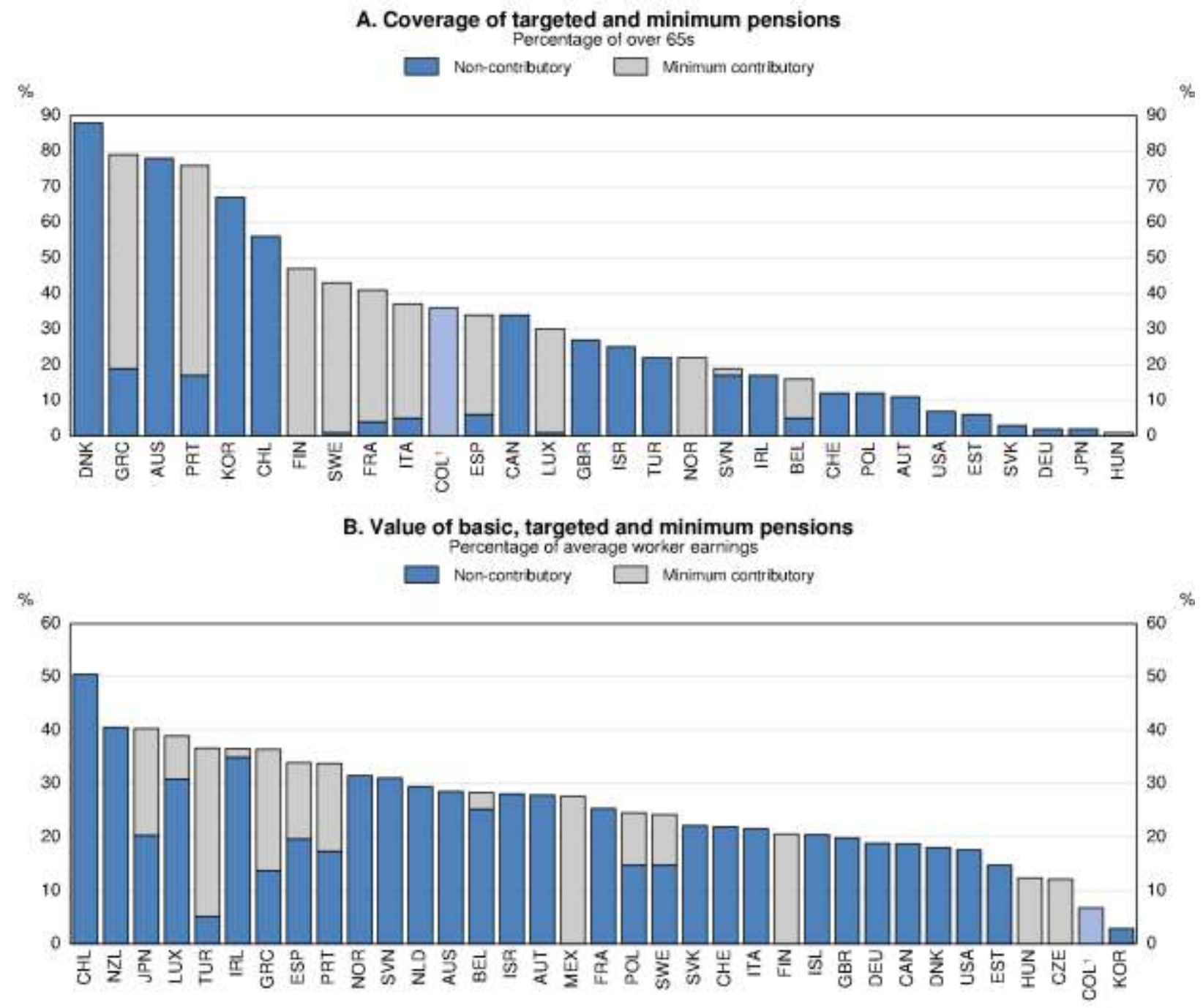

1. For Colombia, the data refer to the coverage and value of Colombia Mayor benefits.

Source: National Authorities and OECD (2013b). 
ECO/WKP(2015)53

\section{Key recommendations}

\section{Recommendations on pensions}

- $\quad$ Thoroughly reform the pension system to reduce old-age poverty and inequality.

- $\quad$ Expand eligibility to the Beneficios Económicos Periódicos programme.

- Increase coverage and benefit levels of the public minimum income-support programme (Colombia Mayor).

\section{Further recommendations}

- $\quad$ Encourage annuitisation for the pay-out phase to protect pensioners against longevity risk.

- $\quad$ Lower the replacement rate of the public scheme and base the reference wage on more years of earnings.

- $\quad$ Equalise the retirement age between men and women. In the medium term, increase the retirement age and link it to life expectancy evolution. 


\section{BIBLIOGRAPHY}

Bosch, M., and J. Guajardo (2012), "Labor Market Impacts of Non- Contributory Pensions: The Case of Argentina's Moratorium", IDB Publications, No. 78. 158, IDB, Washington, DC.

Bosch, M., Á. Melguizo and C. Pagés (2013), "Mejores Pensiones Mejores Trabajos, Hacia La Cobertura Universal En América Latina Y El Caribe", Banco Interamericano de Desarrollo.

Carranza, L., Á. Melguizo and D. Tuesta (2012), "Matching Contributions for Pensions in Colombia, Mexico, and Peru: Experiences and Prospects", BBVA Working Paper, No. 12/32.

Carvalho Filho, I.E. (2008), "Old-age Benefits and Retirement Decisions of Rural Elderly in Brazil", Journal of Development Economics, Vol. 86(1), pp. 12-146, April, Elsevier.

Cotlear, D. 2011, "Population Aging: Is Latin America Ready?", No. 2.542, World Bank Publications, April, World Bank, Washington, DC.

Daude, C., J.R. De Laiglesia and A. Melguizo (2014), "Covering the uncovered: Labour informality, pensions and the emerging middle class in Latin America", in Jeff Dayton-Johnson (ed.), Latin America's Emerging Middle Classes, Palgrave Macmillan, forthcoming.

Daude C., S. Perret and B. Brys (2015), "Making Colombia's Tax Policy More Efficient, Fair and Green”, OECD Economics Department Working Paper No. 1234.

Goñi, E. (2013), Pandemic Informality, Inter-American Development Bank, Washington, DC. HelpAge International (2013), "Global Age Watch Index 2013”, Insight report.

Hinz, R. et al. (eds.) (2013), "Matching Contributions for Pensions: A Review of International Experience", World Bank, Washington, DC.

Holzmann R., D.A. Robalino and N. Takayama (2009), "Closing The Coverage Gap - The Role Of Social Pensions and Other Retirement Income Transfers", The International Bank for Reconstruction and Development/The World Bank.

Juárez, L. and T. Pfutze (2012), “The Effects of a Non-Contributory Pension Program on Labor Force

Participation: The Case of 70 y más in Mexico", Monterrey: Instituto Tecnológico de México, mimeo.

Kugler, A. and M. Kugler (2008), "Labor Market Effects of Payroll Taxes In Developing Countries: Evidence From Colombia", NBER Working Paper, No. 13855.

Montenegro Trujillo, S. et al. (2013a), "Distribucion de ingresos en el Sistema pensional y el impacto de algunas medidas de flexibilizacion", Documentos CEDE, No. 32, Universidad de los Andes.

Montenegro Trujillo, S., L.F.J. Salazar and C.A. Hurtado Martilletti (2013b), "Los subsidies pensionales en el regimen de reparto colombiano: reformas parametricas para focalizar correctamente el gasto social del estado", Documentos CEDE, No. 33, Universidad de los Andes. 
OECD (2012), “The OECD Roadmap For The Good Design Of Defined Contribution Pension Plans”.

OECD (2013a), OECD Economic Surveys: Colombia 2013 - Economic Assessment, OECD Publishing.

OECD (2013b), Pensions at a Glance 2013: OECD and G20 Indicators, OECD Publishing.

OECD/IDB/WB (2014), Pensions at a Glance: Latin America and the Caribbean, OECD Publishing.

Olivera J. and B. Zuluaga (2014), "The Ex-Ante Effects of Non-contributory Pensions in Colombia and Peru", Journal of International Development.

Pallares-Miralles, M., C. Romero and E. Whitehouse (2012), "International Patterns of Pension Provision IIA Worldwide Overview of Facts and Figures", World Bank Discussion Paper, No. 1211.

Rodrigues de Oliveira, P. and A.L. Kassouf (2012), "Impact Evaluation of the Brazilian Non-contributory Pension Program Benefício de Prestação Continuada (BPC) on Family Welfare", Quebec: Partnership for Economic Policy.

Santa Maria, M. et al. (2010), "El systema pensional en Colombia: retos y alternativas para aumentar la cobertura", Informe final, Fedesarollo.

Santa María, M. and G.A. Piraquive Galeano (2013), "Evolucion y alternativas del Sistema pensional en Colombia”, Documento, No. 398, Departemento Nacional de Planeacion, Archivos de Economía. 


\section{WORKING PAPERS}

The full series of Economics Department Working Papers can be consulted at www.oecd.org/eco/workingpapers

1234. Making Colombia's tax policy more efficient, fair and green

(May 2015) by Christian Daude, Sarah Perret and Bert Brys

1233. Skills and labour market performance in Sweden

(May 2015) by Margherita Bussi and Jon Kristian Pareliussen

1232. Skills and inclusive growth in Sweden

(May 2015) by Jon Kristian Pareliussen, Margherita Bussi, Christophe André and Vincent Koen

1231. Incorporating anchored inflation expectations in the Phillips Curve and in the derivation of OECD measures of equilibrium unemployment

(May 2015) by Elena Rusticelli, David Turner and Maria Chiara Cavalleri

1230. Macroeconomic uncertainties, prudent debt targets and fiscal rules,

(July 2015) by Falilou Fall and Jean-Marc Fournier

1229. Limits to government debt sustainability

(July 2015) by Jean-Marc Fournier and Falilou Fall

1228. Government debt indicators: understanding the data

(July 2015) by Debbie Bloch and Falilou Fall

1227. The costs of flexibility-enhancing structural reforms: a literature review

(July 2015) by Tito Boeri, Pierre Cahuc and André Zylberberg

1226. Household finance and income inequality in the euro area

(June 2015) Oliver Denk and Alexandre Cazenave-Lacroutz

1225. Financial sector pay and labour income inequality: evidence from Europe

(June 2015) by Oliver Denk

1224. Finance and income inequality in OECD countries

(June 2015) by Oliver Denk and Boris Cournède

1223. Finance and economic growth in OECD and G20 countries

(June 2015) by Boris Cournède and Oliver Denk

1222. What impedes household investment in energy efficiency and renewable energy?

(May 2015) by Nadia Ameli and Nicola Brandt

1221. Recent trends in productivity in China - shift-share analysis of labour productivity growth and the evolution of the productivity gap

(May 2015) by Margit Molnar and Thomas Chalaux

1220. Assessing China's skills gap and inequalities in education

(May 2015) by Margit Molnar, Boqing Wang and Ruidong Gao 
1219. Providing the right skills to all in China - from "made in China" to "created in China" (May 2015) by Margit Molnar and Vincent Koen

1218. Agricultural reforms and bridging the gap for rural China

(May 2015) by Ben Westmore

1217. A snapshot of China's service sector

(May 2015) by Margit Molnar and Wei Wang

1216. Does the post-crisis weakness of global trade solely reflect weak demand?

(May 2015) by Patrice Ollivaud and Cyrille Schwellnus

1215. Estonia: raising productivity and benefitting more from openness

(May 2015) by Andreas Kappeler

1214. Estonia: making the most of human capital

(May 2015) by Andrés Fuentes Hutfilter

1213. The Czech labour market: documenting structural change and remaining challenges (May 2015) by Sónia Araújo and Petr Malecek

1212. Reforming the Slovak public sector

(April 2015) by Lilas Demmou and Robert Price

1211. Spurring growth in lagging regions in the Slovak Republic

(April 2015) by Lilas Demmou, Gabriel Machlica, Martin Haluš and Robert Menkyna

1210. Skill mismatch and public policy in OECD countries

(April 2015) by Müge Adalet McGowan and Dan Andrews

1209. Labour market mismatch and labour productivity: evidence from PIAAC data

(April 2015) by Müge Adalet McGowan and Dan Andrews

1208. Maintaining an efficient and equitable housing market in Belgium

(April 2015) by Sanne Zwart

1207. Determinants of the low female labour force participation in India

(April 2015) by Piritta Sorsa, Jan Mares, Mathilde Didier, Caio Guimaraes, Marie Rabate,

Gen Tang and Annamaria Tuske

1206. Strengthening skill use and school-to-work transitions in the Czech Republic

(April 2015) by Sónia Araújo and Petr Malecek

1205. Reforming the tax on immovable property: taking care of the unloved

(April 2015) by Hansjörg Blöchliger

1204. Taxation and investment in Colombia

(April 2015) by Sarah Perret and Bert Brys

1203. Efficiency and contestability in the Colombian banking system

(April 2015) by Christian Daude and Julien Pascal 